\title{
ULTRASONIG PROPERTIES OF PLASTICALLY DEFORMED ICE
}

\author{
By J. Tatibouet, R. Vassoille and J. Perez \\ (Laboratoire de Physique des Matériaux - E.R.A. No. $46_{3}$, Institut National des Sciences \\ Appliquées de Lyon, 6962 I Villeurbanne, France)
}

\begin{abstract}
Many authors have used propagation of ultrasonic waves in ice for glaciological studies. This propagation is characterized by the velocity of sound and by the attenuation of stress waves. In crystalline materials, these two characteristics depend on structural state. In particular plastic deformation gives velocity and attenuation variations.

We have measured the sound velocity and attenuation of ultrasonic waves in strained specimens of ice (single crystals and polycrystals). These measurements done between 100 and $273 \mathrm{~K}$ at a frequency of $5 \mathrm{MHz}$ show that plastic deformation leads to an increase of attenuation and an increase of velocity. Annealing treatments at $271 \mathrm{~K}$ cause recovery of propagation characteristics. The variation in attenuation can be interpreted by the theory of dislocations and this interpretation is supported by our data on the influence of frequency on this increase of attenuation induced by plastic deformation, but the theory of dislocations implies a decrease of modulus, i.e. of velocity, hence we must postulate that an added phenomenon screens the effect of dislocations. That phenomenon could be connected with ageing effects observed on different physical properties of ice and may be due to modification of protonic arrangement or creation of interstitials during plastic deformation. Thus our experiments show that it is necessary to be careful in using results determined from the propagation of ultrasonic waves in ice.
\end{abstract}

RÉsumé. Propriétés ultrasonores de la glace deformée plastiquement. Différents auteurs ont utilisé la propagation des ondes ultrasonores dans la glace pour des études glaciologiques. Cette propagation est caractérisée par la vitesse du son et par l'atténuation des ondes de contrainte. Dans les matériaux cristallins, ces deux caractéristiques dépendent de l'état structural. En particulier la déformation plastique entraine des variations de vitesse et d'atténuation.

Nous avons effectué des mesures de vitesse et d'atténuation d'ondes ultrasonores dans des spécimens déformés de glace (monocristaux et polycristaux). Ces mesures faites entre roo et $273 \mathrm{~K}$ à une fréquence de $5 \mathrm{MHz}$ montre que la déformation plastique conduit à une augmentation de l'atténuation et une augmentation de la vitesse. Des traitements de recuit à $271 \mathrm{~K}$ provoquent une restauration des caractéristiques de propagation. La variation de l'atténuation peut être interprétée par la théorie des dislocations. Cette interprétation est d'ailleurs renforcéc par le résultat des mesures en fonction de la fréquence, mais la théorie des dislocations implique une diminution du module c'est-à-dire de la vitesse. Nous sommes donc amenés à penser qu'un phénomène supplémentaire masque l'effet des dislocations. Ce phénomène peut être relié à des effets de vieillissements observés sur d'autres grandeurs physiques et peut être dû à la modification de l'arrangement protonique où à la création d'interstitiels pendant la déformation plastique. Ainsi, nos expériences montrent qu'il est nécessaire d'être prudent dans l'utilisation de résultats liés à la propagation des ondes ultrasonores dans la glace.

Zusammenfassung. Ultraschall-Eigenschaften von plastisch verformtem Eis. Viele Autoren haben die Fortpflanzung von Ultraschallwellen in Eis für glaziologische Studien herangezogen. Diese Fortpflanzung ist durch die Schallgeschwindigkeit und durch die Dämpfung von Spannungswellen gekennzeichnet. In kristallischen Stoffen hängen beide Parameter vom strukturellen Zustand ab. Insbesondere führt die plastische Deformation zu Änderungen der Geschwindigkeit und der Dämpfung.

Die Schallgeschwindigkeit und -dämpfung von Ultraschallwellen in belasteten Eisproben (Einkristalle und Mehrfachkristalle) wurde von uns gemessen. Diese Messungen fanden bei Temperaturen zwischen Ioo und $273 \mathrm{~K}$ mit einer Frequenz von $5 \mathrm{MHz}$ statt; sie zeigten, dass plastische Deformation eine Zunahme sowohl der Geschwindigkeit wie der Dämpfung zur Folge hat. Härtungsmassnahmen bei 27 I K stellen die Fortpflanzungseigenschaften wieder her. Die Änderung der Dämpfung kann durch die Versetzungstheorie erklärt werden. Die Erklärung wird durch unsere Beobachtungen über den Einfluss der Frequenz auf die durch plastische Deformation verursachte Dämpfungszunahme gestützt. Da jedoch aus der Versetzungstheorie eine Abnahme des Moduls, also der Geschwindigkeit, folgt, müssen wir annehmen, dass eine zusätzliche Erscheinung die Wirkung der Versetzungen abschirmt. Diese Erscheinung könnte mit Alterungseffekten, die sich über verschiedene physikalische Eigenschaften des Eises zeigten, verknüpft sein und dürfte auf der Änderung in der Protonenanordnung oder dem Auftreten von Zwischenräumen während der plastischen Verformung beruhen. So zeigen unsere Versuche, dass man bei der Verwendung von Ergebnissen, die aus der Fortpflanzung von Ultraschallwellen im Eis hergeleitet sind, vorsichtig sein muss.

\section{INTRODUCTION}

Sonic waves are commonly used in geophysical studies of glaciers (Lliboutry, 1964-65, Tom. 2, p. $53^{8-51}$ ). This technique has led several authors to utilize sonic wave propagation in the study of ice sheets. Accordingly, they have investigated velocity and attenuation of acoustic waves during their propagation in ice sheets and glaciers (Millecamps and Lafargue, 
1957; Westphal, 1965; Langleben, 1969). Attenuation values in glacier ice are strongly dependent on the experimental location and experimental conditions. For example, frequency is a dominant factor and attenuation increases rapidly with frequency. The principal aim of laboratory experiments is to clarify the variables of acoustical experiments and allow for more precise field measurements, especially those dealing with ultrasonic waves (Kahane, unpublished; Dantl, r 968 ; Helmreich, unpublished).

In crystalline materials, it has been observed that the microstructure has an important influence on velocity and attenuation of ultrasonic waves, in addition to the effect of macroscopic defects (bubbles, cracks). The aim of this work is to show how the microstructure of ice influences ultrasonic propagation. In particular, we shall deal with the effect of plastic deformation on attenuation and velocity of ultrasonic waves. In effect, the motion of dislocations induced by stress waves is the cause of some anelastic phenomena. Several energydissipation models in the ultrasonics range have been proposed in the literature (Granato and Lücke, 1956; Suzuki and Elbaum, ig64). In our work, the attenuation and velocity of longitudinal ultrasonic waves have been determined over a temperature range from Ioo to $273 \mathrm{~K}$ with frequencies varying from I to I $80 \mathrm{MHz}$, using single crystals and polycrystalline specimens plastically deformed by creep. Annealing treatments were made in order to recover the anelastic properties observed before plastic deformation.

\section{EXPERIMENTAL TEGHNiQue}

The apparatus used has been described by Guenin and others (1972). It consists of a MATEC gooo unit (pulse-echo method), an interferometer, and a measurement cell. Attenuation is measured by calibrated exponentials delivered by the MATEC unit and which are superimposed on successive echoes. The measurement range is between o.or and $4 \mathrm{~dB} / \mu \mathrm{s}$. The specimens $\left(15 \mathrm{~mm} \times \mathrm{I}_{5} \mathrm{~mm} \times 40 \mathrm{~mm}\right.$ ) are mechanically cut and po.ished. Tro opposite faces are made parallel with a special mould and silk-polished in order to obtain strong reflections of successive pulses of the ultrasonic waves. The length of the specimens is measured with a micrometer at $253 \mathrm{~K}$. The problem of a bonding agent between ice and the quartz transducer is solved by the use of methyl-4. I-pentane. Specimens are compressed in a dead-weight creep machine up to $5 \%$ strain at $260 \mathrm{~K}$. The opposite faces are repolished and rectified after every creep test.

The monocrystalline ice is obtained from the Laboratoire de Spectrometrie Physique de Grenoble. The $c$-axis orientation is determined between two crossed polaroids and more precisely by X-ray diagrams. The conductivity of the water obtained by subsequent melting of specimens is $0.8 \times 10^{-4} \Omega^{-1} \mathrm{~m}^{-1}$.

\section{Results}

The attenuation has been determined as a function of temperature for monocrystalline specimens for two different angles $\phi$ between stress waves and $c$-axis (i.e. $\phi=0^{\circ}$ and $\phi=45^{\circ}$ ). Figure i shows attenuation versus temperature for a $\phi=45^{\circ}$ specimen, before deformation, after $5 \%$ strain, and after annealing treatments ( $150 \mathrm{~h}$ and $300 \mathrm{~h}$ at $27 \mathrm{I} \mathrm{K}$ ). Attenuation increases considerably with strain. A micrographic study shows glide bands parallel to the basal plane of the crystals, consistent with basal glide on the system (OOOI) $\langle\mathrm{I} I \overline{2} \mathrm{O}\rangle$. After I $5^{\circ} \mathrm{h}$ at $27 \mathrm{I} \mathrm{K}$ recrystallization occurs and new grains appear. The recovery of attenuation is nearly complete after $300 \mathrm{~h}$ at $27 \mathrm{I} \mathrm{K}$.

Similar curves are shown for a $\phi=0^{\circ}$ specimen in Figure 2. The increase after deformation is weaker than for the $\phi=45^{\circ}$ specimen. The recovery after $300 \mathrm{~h}$ at $27 \mathrm{I} \mathrm{K}$ is less complete. Unlike the $\phi=45^{\circ}$ specimen, a micrographic study does not show glide bands and the specimen becomes barrel-shaped after plastic deformation. As in the former case, new grains are observed after $300 \mathrm{~h}$ annealing. 


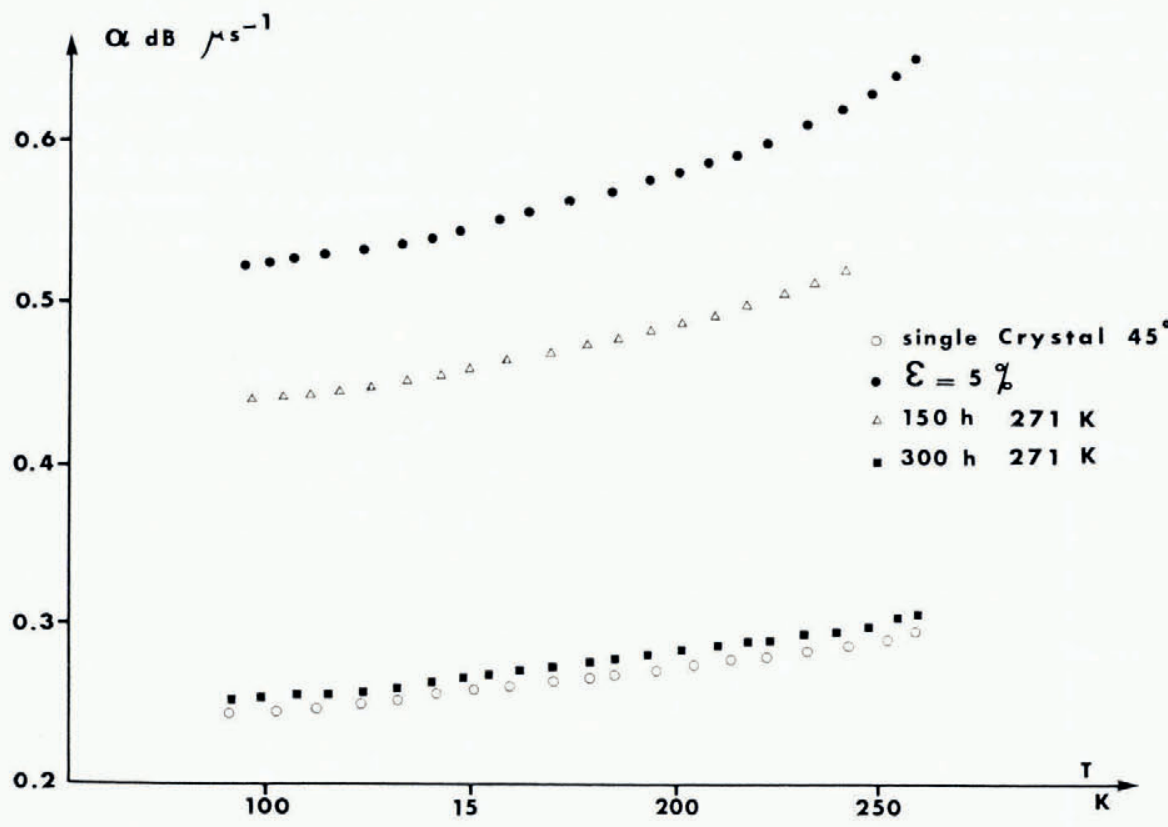

Fig. I. Attenuation versus temperature, $\phi=45^{\circ}$ specimen.

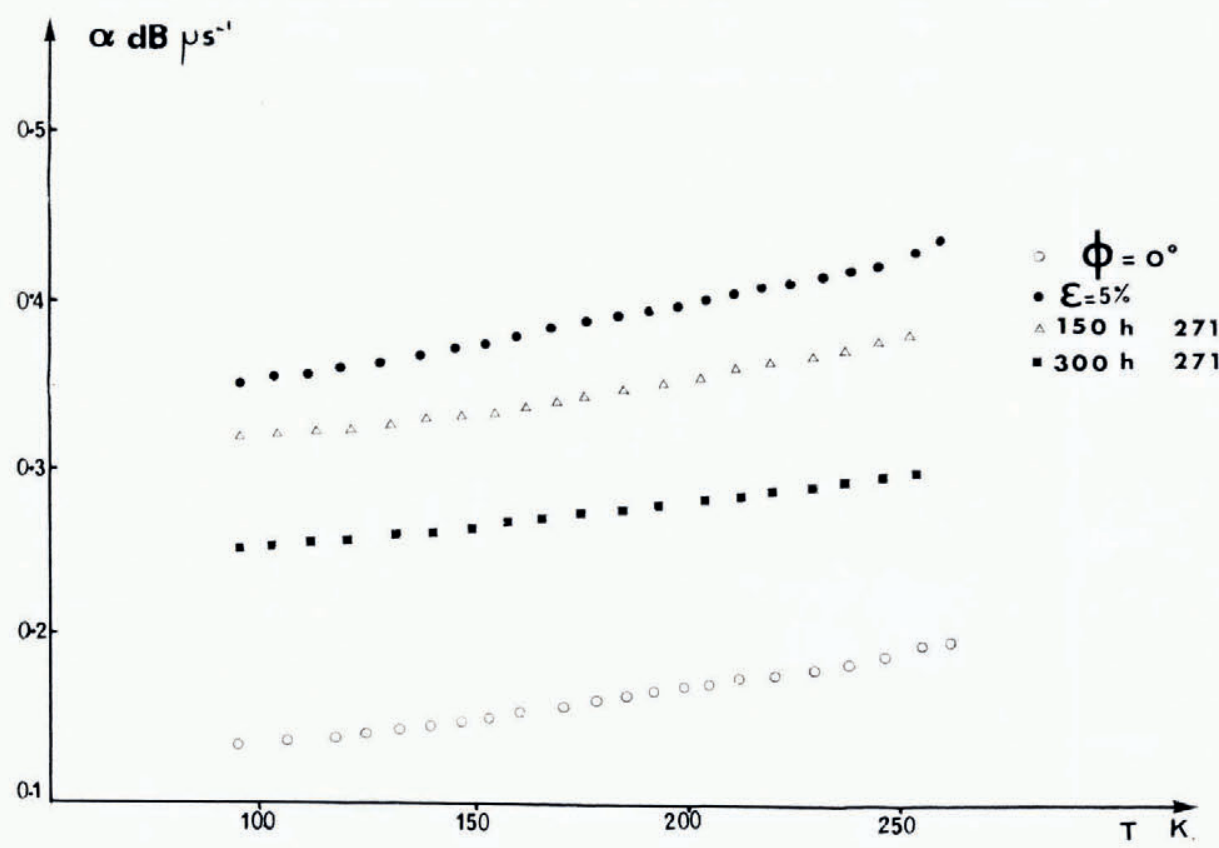

Fig. 2. Attenuation versus temperature, $\phi=0^{\circ}$ specimen. 
Velocity variations are calculated from the transit time of ultrasonic waves in specimens, thermal expansion being taken into account in the calculation of velocity of sound. Figures 3 and 4 show velocity versus temperature before and after deformation, and after annealing treatments. In both cases $\left(\phi=0^{\circ}\right.$ and $\left.\phi=45^{\circ}\right)$ plastic deformation has lead to an increase of wave velocity. After annealing treatments a decrease of velocity is observed, but not a complete recovery of the initial values. Figure 5 shows attenuation versus strain for poly- and mono-crystalline specimens. To specify the variations of propagation characteristics due to deformation we have collected on Figure 6 attenuation values versus wave frequency for a

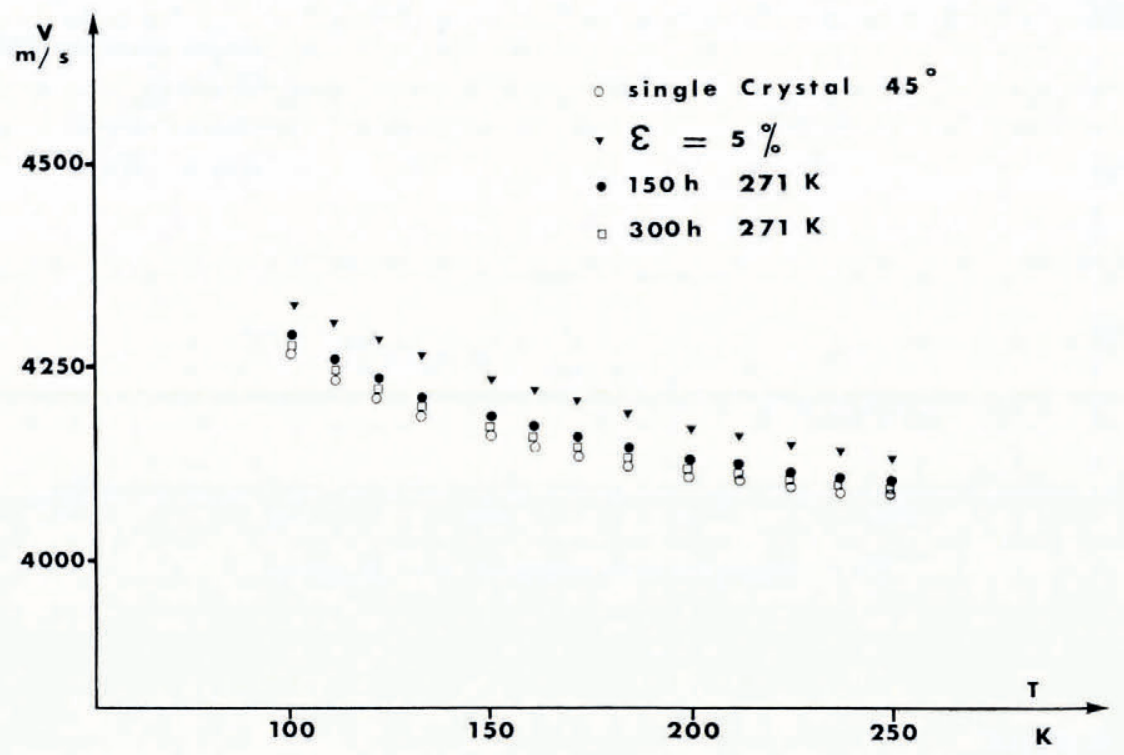

Fig. 3. Velocity versus temperature, $\phi=45^{\circ}$ specimen.

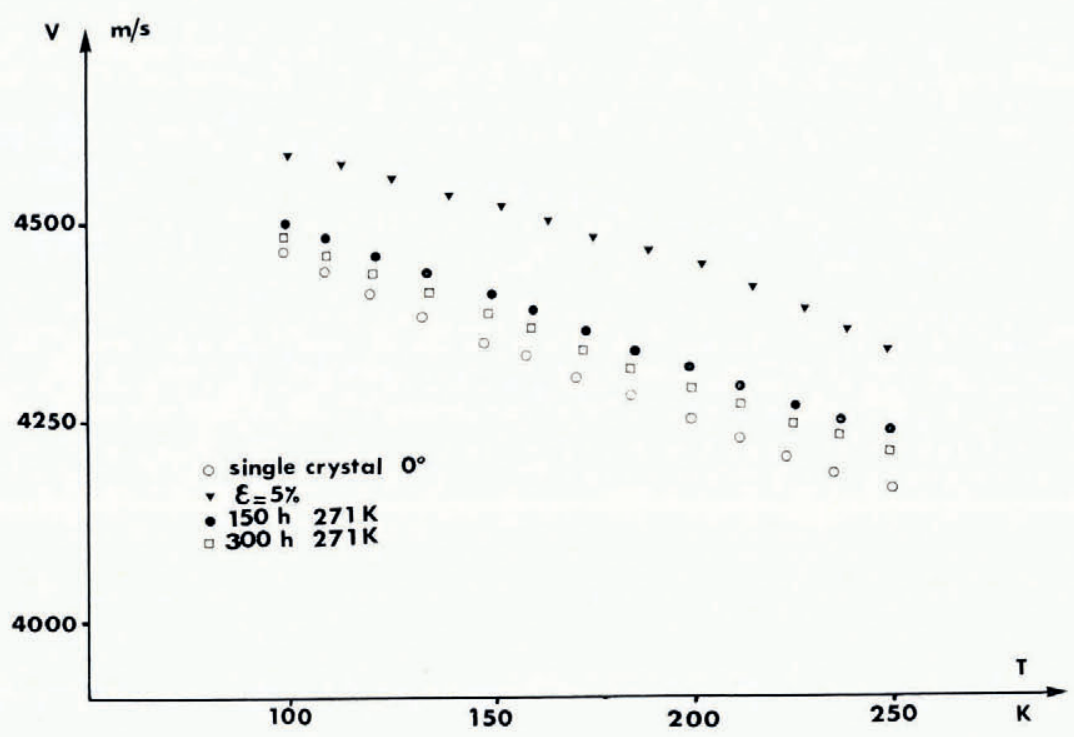

Fig. 4. Velocity versus temperature, $\phi=o^{\circ}$ specimen. 


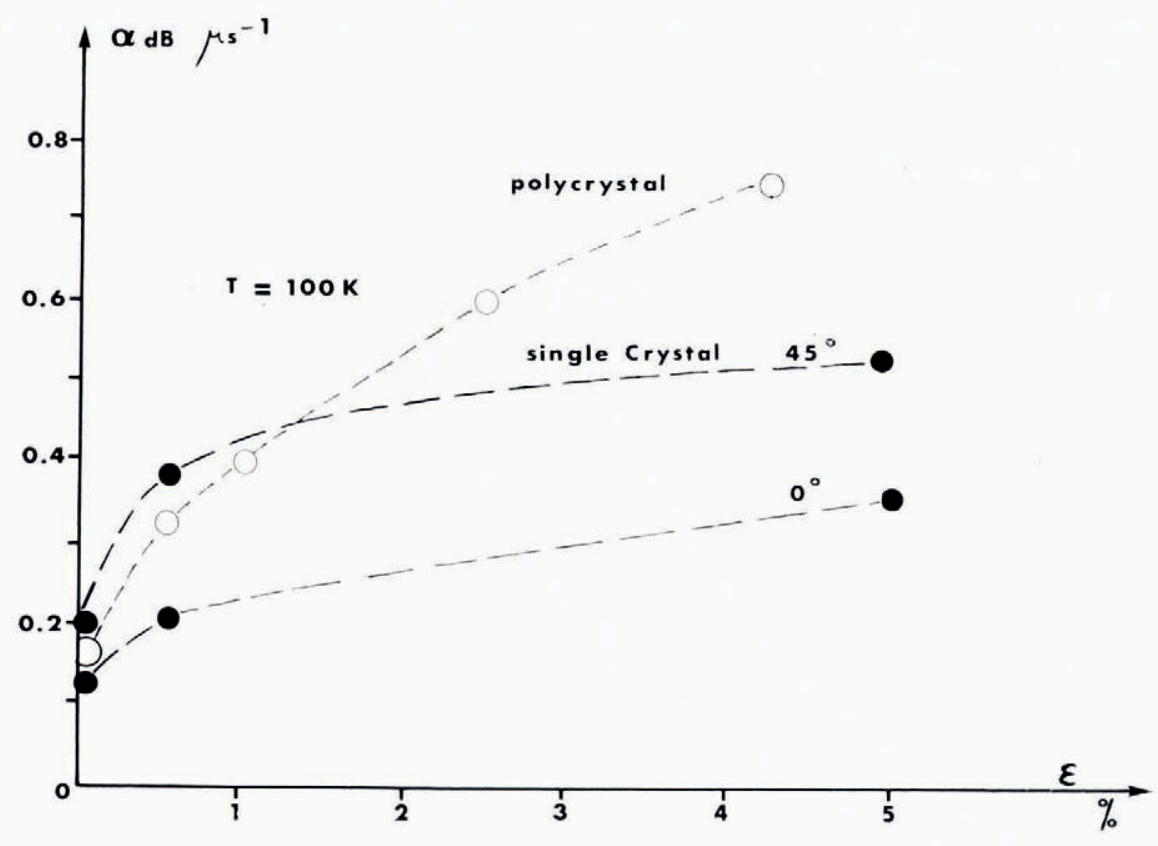

Fig. 5. Attenuation versus strain.

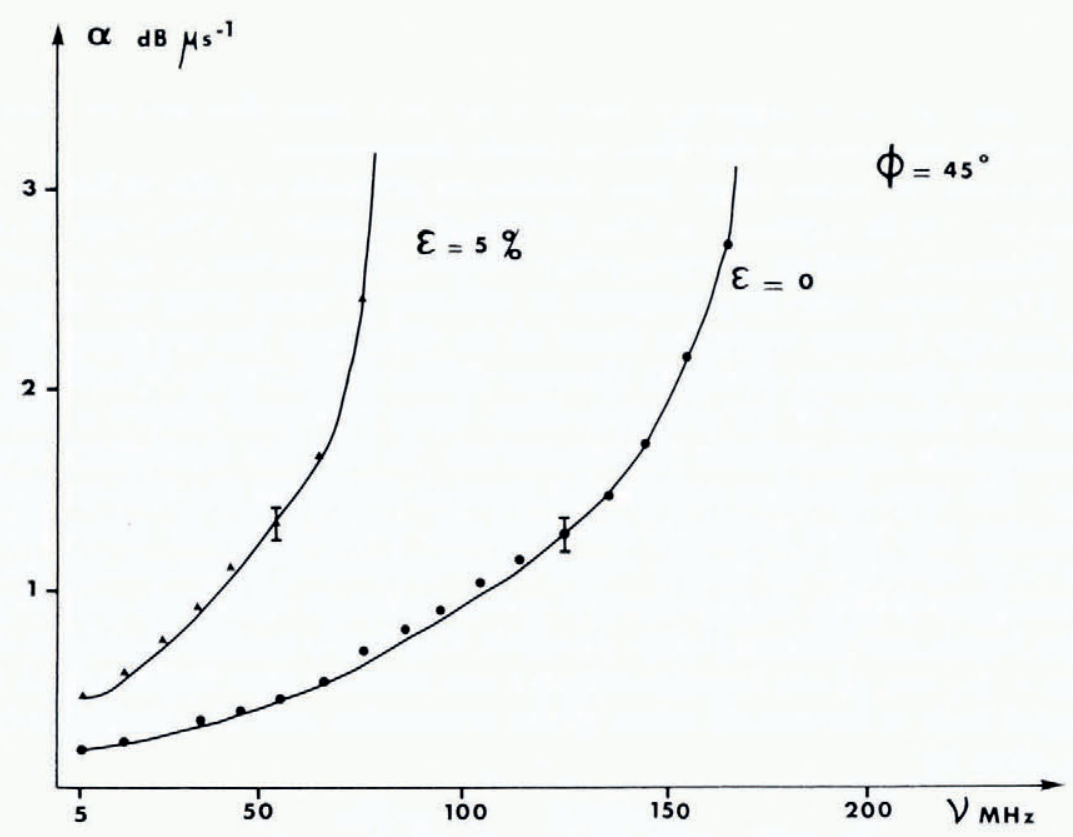

Fig. 6. Attenuation versus frequency, $\phi=45^{\circ}$ specimen. 
$\phi=45^{\circ}$ specimen before and after deformation $(\epsilon=5 \%)$. Very high values of attenuation are reached above $75 \mathrm{MHz}$ for the strained specimen. Figure 7 shows similar results for a $\phi=0^{\circ}$ specimen strained only $2 \%$.

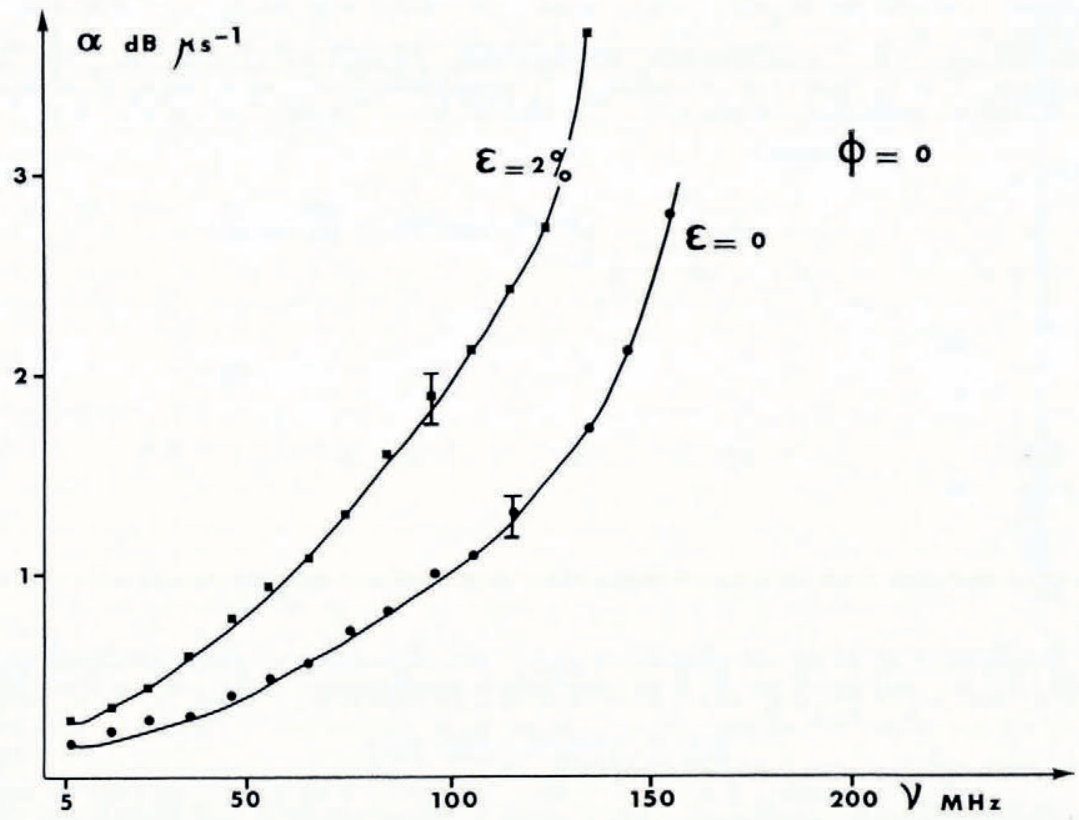

Fig. 7. Attenuation versus frequency, $\phi=0^{\circ}$ specimen .

\section{Discussion}

Causes of attenuation of ultrasonic waves in ice have been discussed by Dantl (1968). We shall limit the discussion to the effects of plastic deformation.

In our ultrasonic frequency range, point defects are generally not able to induce a measurable attenuation. On the contrary, motion of dislocations under a stress wave is responsible for energy dissipation leading to attenuation. Dislocation motion in ice is not yet fully explained. This motion may be considered as diffusion of kinks along the dislocation line and is possible only if water molecules ahead of the dislocation line are favorably oriented. This orientation is made easy, thanks to Bjerrum defects (Glen, I968). If such motion really occurs under the influence of the ultrasonic stress wave, we should observe a strong dependence of propagation characteristics on temperature. In fact, this dependence is very weak (Fig. I to 4). We must therefore consider the forward movement of a kink as limited to the distance between two water molecules not favorably oriented and its mean value can be taken equal to $2 b$ where $b$ is the Burgers vector of the dislocation (Perez and others, in press).

The assumption of kink motion has led us to an energy dissipation model previously developed by Suzuki and Elbaum (1964). In effect, if the strain associated with the stress wave is weak (this is the case of our experiments), we can consider kink displacements less than $b$ and this model leads to theoretical values of the attenuation and velocity anomaly of ultrasonic waves given by:

$$
\alpha=8.68 \times 10^{-6} \frac{4 G b^{4} \mathcal{N}}{\pi^{2} m} \frac{\omega^{2} B / m}{\left(\omega^{2}-\omega_{0}^{2}\right)^{2}+\omega^{2}(B / m)^{2}},
$$




$$
\frac{\Delta v}{v}=\frac{v-v_{0}}{v_{0}}=4 \frac{G b^{4}}{\pi^{2} m} \mathcal{N} \frac{\omega^{2}-\omega_{0}^{2}}{\left(\omega^{2}-\omega_{0}^{2}\right)^{2}+\omega^{2}(B / m)^{2}},
$$

where $\alpha$ is the attenuation in $\mathrm{dB} / \mu \mathrm{s}, G$ the shear modulus, $m$ the effective mass of a kink, $\mathcal{N}$ the density of kinks, $\omega$ the wave frequency $(\omega=2 \pi \nu), \omega_{0}$ the resonance frequency of kink, $B$ the damping coefficient, and $v$ and $v_{0}$ are the wave velocity in the crystal with and without dislocations respectively.

If frequency $\omega$ is small compared with $\omega_{0}$ we can consider the simplified relation:

$$
\alpha=8.68 \times 10^{-6} \frac{\mathrm{I} 6 G b^{4} \mathcal{N} B}{m^{2} \omega_{0}^{4}} \nu^{2} .
$$

In order to verify the variation of attenuation with frequency we have plotted in Figure 8 the attenuation due to plastic deformation versus frequency squared from our results of Figures 6 and 7. To the first approximation this law is verified, and shows that the increase of attenuation can be due to dislocations.

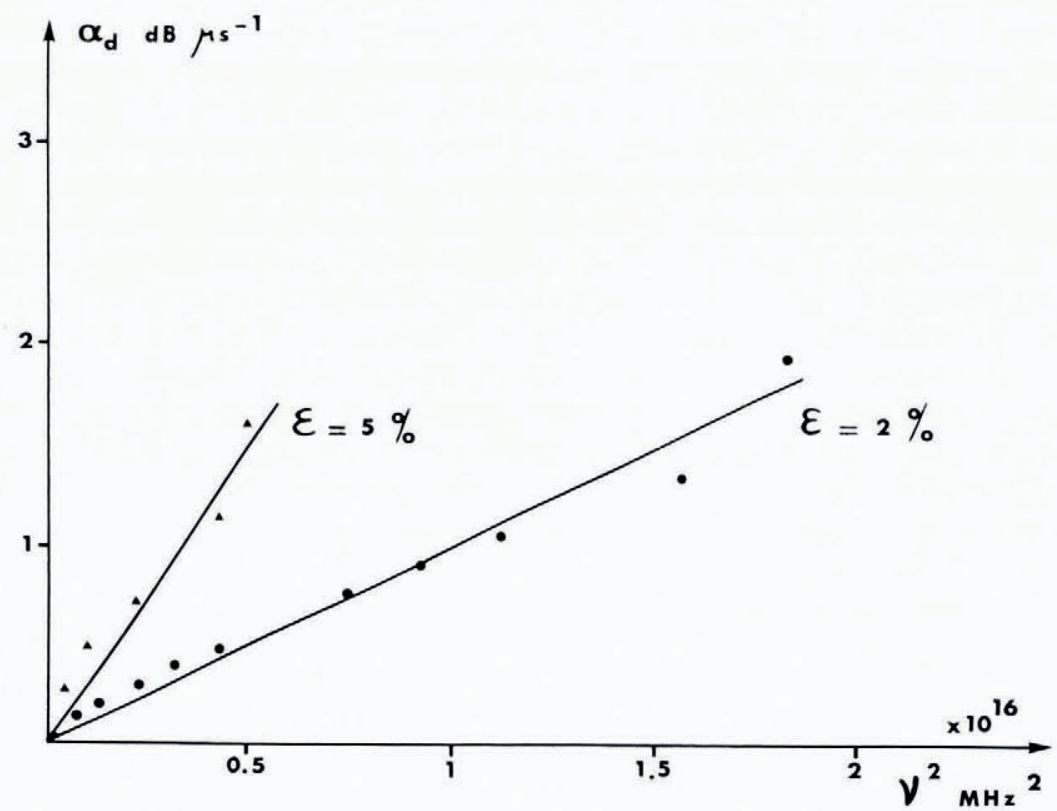

Fig. 8. Attemuation due to plastic deformation versus square of frequency. $\alpha_{\mathrm{d}}=$ difference between attenuation after deformation and attenuation before deformation.

With usual values for ice (Suzuki and Elbaum, r 964 ; Vandevander and Itagaki, r973): $G=3.5 \times 10^{9} \mathrm{~N} \mathrm{~m}^{-2}, b=4.5 \times 10^{-10} \mathrm{~m}, m \approx \mathrm{IO}^{-25} \mathrm{~kg}, B=5 \times 1 \mathrm{O}^{-17} \mathrm{~kg} \mathrm{~s}^{-1}$, an estimation of $\omega_{0}$ for the $5 \%$ and $2 \%$ strained specimen of

$$
\begin{aligned}
& \omega_{0}(5 \%)=5.5 \times 10^{8} \mathrm{~s}^{-1}, \\
& \omega_{0}(2 \%)=9 \times 10^{8} \mathrm{~s}^{-1},
\end{aligned}
$$

and a value of $\mathcal{N}$ of $10^{12} \mathrm{~cm}^{-3}$ (which corresponds to a dislocation density $10^{6} \mathrm{~cm}^{-2}$ ), we have found a good agreement between theoretical and experimental values for attenuation $\left(\alpha_{\exp }=0.25 \mathrm{~dB} / \mu \mathrm{s} ; \alpha_{\mathrm{th}}=0.2 \mathrm{~dB} / \mu \mathrm{s}\right)$. However the theoretical value of the velocity 
anomaly, $\Delta v / v \approx-9 \times 10^{-3}$, corresponds to a decrease of velocity. In our experiments we have found an increase of $2 \%$ after plastic deformation. If the increase of attenuation is to be rationally explained on the Suzuki and Elbaum model, velocity variation is certainly not due only to the increase of dislocation density after plastic deformation.

The recrystallization on one hand, and the difference between the $\phi=45^{\circ}$ and $\phi=0^{\circ}$ specimens on the other hand, confirm that dislocations play a role in the characteristics of propagation of ultrasonic waves. In effect, the principal glide system (basal plane) is easily activated during creep in the case of $\phi=45^{\circ}$, but the situation is not so simple in the case $\phi=$ $0^{\circ}$. One can think that either there is a sufficiently high component of stress in the basal plane due to experimental difficulties in cutting specimens exactly with $\phi=0^{\circ}$ angle, or, an alternative suggestion worth examination, non-basal glide may be considered. The former assumption is in agreement with the fact that the yield stress for non-basal system is roughly ten times that of basal glide. The latter assumption has received support from the works of Muguruma and Higashi (1963), Tegart (1964), and Levi and others (1965).

But whatever assumption is considered, plastic deformation leads to a different structure and/or distribution of dislocations and that may explain the difference observed between the two types of specimens. Furthermore, since recrystallization occurs after annealing treatments in both cases, microstructure becomes similar. So the same values of attenuation after annealing are to be expected. The anomalous result for velocity seems to us to be connected with the observations of Dantl (1969) dealing with elastic constant measurements; ageing effects were observed which led to decreases of modulus and of density of freshly grown ice. This effect is not yet very well explained and it could be due, either to a protonic rearrangement leading to equilibrium during the ageing process, or a decrease of the number of interstitial water molecules to the value of thermal equilibrium concentration.

During our experiments, we think that plastic deformation leads the ice to a structure similar to that of freshly grown material. In other words, plastic deformation may be responsible for protonic rearrangement or formation of interstitial water molecules, and that could explain the increase of velocity we have observed. This effect on velocity can be quantitatively compared with the ageing effects on modulus and on density as reported by Dantl (1969) (respectively $-5 \%$ and $-3 \%$ ) which correspond to a decrease of velocity of $2.3 \%$. This value is of the same order as our experimental values as can be seen on Figures 3 and 4. In addition, the experiments of Noll (1973) concerning dielectric properties of strained ice are in agreement with this assumption.

Annealing treatments at $27 \mathrm{I} \mathrm{K}$ allow an ageing effect which recovers properties, in particular velocity, screening variations connected with the dislocation density modification. Furthermore kinetics for the recoveries of velocity and attenuation are not similar; recovery of attenuation agrees with the recrystallization kinetics found by Steinemann (1954) but the velocity recovery is faster. This last point confirms the existence of two processes for modification of the characteristics of propagation when plastic deformation of ice occurs.

\section{Conclusion}

We have shown that the propagation characteristics of ultrasonic waves are strongly dependent on the microstructure of ice. Plastic deformation leads to an increase of the velocity and especially of the attenuation. In order to explain this effect, we have considered two different processes. In effect, the multiplication of linear defects during plastic deformation cannot explain increases of both attenuation and velocity. We must also consider that plastic deformation leads ice to a structure similar to that of freshly grown material. Consequently our work shows that it is necessary to be careful in explaining and using results obtained from experiments dealing with acoustic and ultrasonic wave propagation in ice. 


\section{REFERENCES}

Dantl, G. 1968. Die mechanische Dämpfung in Eis-Einkristallen. Zeitschrift für Physik, Bd. 215 , Ht. 5, p. 481-84.

Dantl, G. 1969. Elastic moduli of ice. (In Riehl, N., and others, ed. Physics of ice: proceedings of the inte national symposium on physics of ice, Munich, Germany, September 9-14, 1968. Edited by $\mathcal{N}$. Riehl, B. Bullemer, H. Engelhardt. New York, Plenum Press, p. 223-30.)

Glen, J. W. 1968. The effect of hydrogen disorder on dislocation movement and plastic deformation of ice. Physik der kondensierten Materie, Bd. 7, Ht. 1, p. 43-51.

Granato, A., and Lücke, K. 1956. Theory of mechanical damping due to dislocations. Journal of Applied Physics, Vol. 27, No. 6, p. 583-93.

Guenin, G., and others. 1972 . Recovery of ultrasonic properties during annealing of cold worked lithium fluoride, [by] G. Guenin, J. Perez and P. F. Gobin. Crystal Lattice Defects, Vol. 3, No. 4, p. I99-205.

Helmreich, D. Unpublished. Anomales elastisches Verhalten von Eis bei tiefen Temperaturen. [Diploma thesis, Technische Hochschule München, r968.]

Kahane, A. Unpublished. Recherches expérimentales et théoriques sur les propriétés optiques et la structure de la glace. [Doctorat d'État thesis, Université de Paris, I962.]

Langleben, M. P. 1969. Attenuation of sound in sea ice, 10-50o kHz. Journal of Glaciology, Vol. 8, No. 54, p. $399-406$.

Levi, L., and others. 1965. Experimental study of non-basal dislocations in ice crystals, by L. Levi, E. M. de Achaval and E. Suraski. Journal of Glaciology, Vol. 5, No. 4i, p. 69i-99.

Lliboutry, L. A. 1964-65. Traité de glaciologie. Paris, Masson et Cie. 2 vols.

Millecamps, R. G., and Lafargue, M. 1959. Sur la propagation des ultrasons dans un glacier. Comptes Rendus Hebdomadaires des Séances de l'Académie des Sciences (Paris), Tom. 244, No. 23, p. 2824-27.

Muguruma, J., and Higashi, A. I963. Observation of etch channels on the (Ooo I) plane of ice crystal produced by nonbasal glide. Fournal of the Physical Society of Japan, Vol. 18, No. 9. p. 1261-69.

Noll, G. 1973. Influence of plastic deformation on the electrical properties of Ice Ih single crystals. (In Whalley, E., and others, ed. Physics and chemistry of iced: papers presented at the Symposium on the Physics and Chemistry of Ice, held in Ottawa, Canada, I4-18 August 1972. Edited by E. Whalley, S. F. Jones, L. W. Gold. Ottawa, Royal Society of Canada, p. $35^{\circ}-55$.)

Perez, J., and others. In press. Comportement dynamique des dislocations dans la glace, par J. Perez, J. Tatibouet, R. Vassoille et P. F. Gobin. Philosophical Magazine.

Steinemann, S. [1956]. Flow and recrystallisation of ice. Union Géodésique et Géophysique Internationale. Association Internationale d'Hydrologie Scientifique. Assemblée générale de Rome 1954, Tom. 4, p. 449-62.

Suzuki, T., and Elbaum, C. 1964. Dislocation damping due to kink motion. Journal of Applied Physics, Vol. 35, No. 5 , p. ${ }^{1} 539-44$.

Tegart, W. J. M. 1964 . Non-basal slip as a major deformation process in the creep of polycrystalline ice. Fournal of Glaciology, Vol. 5, No. 38, p. $25 \mathrm{I}-54$.

Vandevander, J. P., and Itagaki, K. I973. Internal friction of single crystal ice. U.S. Cold Regions Research and Engineering Laboratory. Research Report 243.

Westphal, J. A. 1965. In situ acoustic attenuation measurements in glacial ice. Journal of Geophysical Research, Vol. 70, No. 8, p. $1849^{-53}$.

\section{DISCUSSION}

S. J. Jones: Do you know the initial dislocation content of your crystals, that is before deformation?

J. Tатівоuet: Unfortunately the initial dislocation density is not known, but similar crystals were studied by Dr Klinger in Grenoble, and such work gives us an estimate of dislocation density of around $\mathrm{IO}^{4} \mathrm{~cm}^{-2}$. 